\title{
Ensamarbetande doktoranders perspektiv på forskarutbildning och doktorandtillvaro: Ämnesmässig ensamhet, den informella socialisationens kraft och erkännandets betydelse. ${ }^{\mathrm{I}}$
}

\author{
Ola Holmström* \\ Avdelningen Kvalitet och utvärdering/Institutionen för Utbildningsvetenskap, Lunds universitet
}

\begin{abstract}
Föreliggande studie bygger på kvalitativa forskningsintervjuer med 26 ensamarbetande doktorander vid Lunds universitet. Studien har sin bakgrund i data från enkätundersökningar som visar att doktorander som arbetar ensamma trivs sämre med sin doktorandtillvaro än doktorander som ingår i en forskargrupp och att detta i högre grad gäller för kvinnor än för män. Mot denna bakgrund är studiens syfte att fördjupa förståelsen för vad som är problematiskt med forskarutbildningen utifrån de ensamarbetande doktorandernas synvinkel och varför situationen verkar vara särskilt problematisk för kvinnor. Intervjumaterialet analyseras primärt utifrån teoretiska perspektiv på ensamhet, socialisation och erkännande. Studiens resultat visar att doktoranders ensamhet ofta är ämnesmässig och relaterar till en känsla av att vara utlämnad till sig själv i avhandlingsarbetet. Studien visar också på kraften i doktoranders informella socialisation, vilken kan lokaliseras till sammanhang och handlingsmönster som doktorander påträffar utanför formella direktiv och riktlinjer. Särskilt problematiseras forskarutbildningsmiljöer som präglas av ett långtgående individualistiskt förhållningssätt till arbetet. I dessa tenderar problem som doktorander kan uppleva att både normaliseras och individualiseras. Därtill beskrivs miljöer med ett långtgående individualistiskt förhållningssätt som särskilt problematiska för kvinnor. Av studien framkommer också att det ibland kan finnas en stor diskrepans mellan doktoranders behov av professionellt erkännande och det faktiska erkännande som de upplever sig få inom ramen för forskarutbildningen.
\end{abstract}

Nyckelord: forskarutbildning, ensamhet, socialisation, erkännande

\section{INLEDNING OCH SYFTE}

I föreliggande artikel redovisas erfarenheter från en intervjustudie med doktorander vid Lunds universitet. Samtliga doktorander som medverkar i studien arbetar ensamma i den meningen att de inte bedriver sitt avhandlingsarbete inom ramen för en forskargrupp. Studiens bakgrund står att finna i 2012/2013 års utvärdering av forskarutbildningen vid Lunds universitet (Holmström, 2013). Utvärderingsstudien bygger på enkätdata och den visar tydligt att ensamarbetande

1 Artikeln är en komprimerad och omarbetad version av en tidigare publicerad rapport (Holmström, 2016).

\footnotetext{
* Författarkontakt: Ola Holmström, ola.holmstrom@stu.lu.se

Artiklar och reflektioner är kollegialt granskade. Övriga bidragstyper granskas av redaktionen. Se www.hogreutbildning.se ISSN 2000-7558

(C)2018 Ola Holmström. This is an Open Access article distributed under the terms of the Creative Commons Attribution-NonCommercial 4.0 International License (https://creativecommons.org/licenses/by-nc/4.0/), allowing third parties to share their work (copy, distribute, transmit) and to adapt it, under the condition that the authors are given credit, that the work is not used for commercial purposes, and that in the event of reuse or distribution, the terms of this license are made clear.

Citation: Ola Holmström (2018) «Ensamarbetande doktoranders perspektiv på forskarutbildning och doktorandtillvaro: Ämnesmässig ensamhet, den informella socialisationens kraft och erkännandets betydelse», Högre utbildning 8, 14-29. http://dx.doi.org/10.23865/hu.v8.1138
} 
doktorander trivs sämre med doktorandtillvaron än de som ingår i en forskargrupp. Detta gäller oberoende fakultet och det tar sig många olika uttryck. Exempelvis uppgav färre av de ensamarbetande doktoranderna (61\%) än de som ingår i en forskargrupp (8I\%) att de trivdes i sin forskarutbildningsmiljö. Vidare hade dubbelt så många av de ensamarbetande doktoranderna (I5\%) jämfört med doktoranderna som ingick i en forskargrupp (7,5\%) tagit kontakt med läkare som en följd av problem i deras arbetssituation. Även sjukskrivningstalet var det dubbla inom gruppen av ensamarbetande doktorander. ${ }^{2}$ Särskilt problematisk var situationen för de ensamarbetande kvinnorna. Så många som var femte ensamarbetande kvinna (2I\%) hade varit i kontakt med läkare och nästan var tionde (8\%) hade varit sjukskriven. ${ }^{3}$ Samma sak gällde för betydligt färre bland kvinnorna som ingick i en forskargrupp. ${ }^{4}$ Mönstret är detsamma inom gruppen av manliga doktorander. Medan IO\% av de ensamarbetande männen hade varit i kontakt med läkare och $4 \%$ hade varit sjukskrivna gällde samma sak för betydligt färre män som var verksamma inom en forskargrupp. ${ }^{5}$

Universitetskanslersämbetets Doktorandspegel från 2016 antyder samma mönster på nationell nivå. Exempelvis visar studien att andelen doktorander som varit sjukskrivna är betydligt högre inom humaniora ( $17 \%)$, där andelen ensamarbetare är stor, än inom medicin och hälsovetenskap samt teknik (6\%) där doktoranderna som regel ingår i en forskargrupp. Av Doktorandspegeln framkommer också tydligt att kvinnor ( $13 \%$ ) är sjukskrivna i högre grad än män ( $5 \%$ ).

Mot denna bakgrund syftar föreliggande studie till att fördjupa förståelsen för den ökade sårbarhet och lägre grad av trivsel som ensamarbetande doktorander ger uttryck för. Vad är problematiskt med forskarutbildningen utifrån de ensamarbetande doktorandernas synvinkel? Hur kommer det sig att doktorander som arbetar ensamma generellt sett verkar trivas sämre med sina forskarstudier än doktorander som ingår i en forskargrupp och varför verkar detta gälla för kvinnor i högre grad än för män? Dessutom diskuteras studiens resultat i ett utvecklingsperspektiv. Vilka lärdomar kan dras utifrån de erfarenheter som intervjupersonerna delar med sig av och hur relaterar resultat och analyser till utvecklingen av forskarutbildningen?

\section{Perspektiv och avgränsningar}

Föreliggande artikel ger framförallt en fördjupad inblick i vilka slags utmaningar och påfrestningar som ensamarbetande doktorander kan möta på sin väg genom forskarutbildningen. Studiens fokus är dock inte liktydigt med att resultat och analyser skulle sakna relevans för andra doktorander än de som arbetar ensamma. Att doktorera ensam eller inom ramen för en forskargrupp handlar om gradvisa skillnader snarare än om några absoluta positioner.

Studiens empiriska material analyseras utifrån teoretiska perspektiv på ensamhet, socialisation och erkännande. Begreppen hänvisar på olika sätt till frågan om individens relation till gruppen. Medan ensamhet handlar om frånvaron av de andra, handlar socialisation om vägen in $\mathrm{i}$ en gemenskap och erkännande om betydelsen av att individens kompetens och prestationer

$26 \%$ av de ensamarbetande och $3 \%$ av doktoranderna i forskargrupp uppgav att de varit sjukskrivna.

3 I sammanhanget kan också noteras att materialet antyder att problem med ensamarbete kan vara än mer påtagligt i gruppen av internationella doktorander. Bland de doktorander som verkade i forskargrupp uppgav nio av tio inom både den svenska och den internationella doktorandgruppen att de trivdes med arbetsformen. Bland ensamarbetande uppgav omkring sex av tio (58\%) internationella och sju av tio (73\%) svenska doktorander att de trivdes med att arbeta ensamma (Holmström, 20I4).

4 Av kvinnorna i forskargrupp hade I0\% kontaktat läkare och $5 \%$ hade varit sjukskrivna.

5 Av männen i forskargrupp hade 5\% kontaktat läkare och I\% hade varit sjukskrivna. 
synliggörs inom gruppen. Därtill diskuteras materialet utifrån ett genusperspektiv, först och främst med hjälp av begrepp som hämtats från doktorandstudier som på olika sätt belyser forskarutbildningen utifrån en könsdimension.

Även om studien primärt utgår från ett doktorandperspektiv kan den också vara intressant att förstå i ljuset av ett handledar- och forskarutbildningsperspektiv. Mot bakgrund av de senaste decenniernas förändringar av svensk forskarutbildning - med ökade regler, tydligare styrning och mer strukturerade studiegångar - har forskarutbildningen blivit alltmer formaliserad och därmed olik de i hög grad oreglerade forskarstudier som tidigare bedrivits. Samtidigt är forskarutbildningen komplex och långt ifrån alla frågor om t.ex. utbildningens utformning eller handledarens ansvarsområden är på förhand formaliserade eller givna. Detta är snarare något som måste diskuteras i den aktuella forskarutbildningsmiljön och i relation till den enskilde doktorandens förutsättningar (Sonesson \& Lindberg-Sand, 20I6). I det arbetet kan doktoranderfarenheterna som förmedlas i den här studien tjäna som ett diskussionsunderlag.

\section{Disposition}

I det följande redogörs för intervjustudiens genomförande och resultat. Först presenteras forskning som på olika sätt belyser doktoranders känslor av ensamhet i forskarstudierna. Därefter redogörs för studiens metod och intervjumaterialet presenteras i ljuset av studiens teoretiska begrepp. Avslutningsvis diskuteras några utvecklingsområden för forskarutbildningen som kan identifieras mot bakgrund av resultat och analyser.

\section{ENSAMHET I FORSKARUTBILDNINGEN: ORSAKER, KONSEKVENSER OCH ÅTGÄRDER}

I forskningslitteraturen är det svårt att finna studier som specifikt behandlar hur ensamarbetande doktorander upplever sin doktorandtillvaro. Däremot utgör doktoranders känslor av ensamhet och sociala isolering ett viktigt forskningsfält (Janson, Howard \& Schoenberger-Orgad, 2004; Jones, 20I3). Inom fältet undersöks såväl varför ensamhetskänslor uppstår som vilka konsekvenser ensamhet har för den enskilde doktorandens forskarstudier. Dessutom diskuteras hur forskarutbilning kan utformas för att motverka ensamhetskänslor.

\section{Varför uppstår känslor av ensamhet i forskarutbildningen?}

En forskarutbildning kan i flera meningar ses som en av de mest individualiserade studiegångar som finns (Sonesson \& Lindberg-Sand, 20I6) och det mest uppenbara skälet till att doktorander kan uppleva social isolering och ensamhet är att forskning och avhandlingsarbete per definition inbegriper mycket solitärt arbete (Jones, 20I3).

Samtidigt är doktoranden i behov av råd, stöd och handledning och detta ligger som grund för ett inneboende spänningsförhållande i forskarstudierna. Å ena sidan ska doktoranden utvecklas mot att bli en självständig forskare, å andra sidan finns ett behov av vägledning i framförallt avhandlingsprocessen. Detta skiljer forskarutbildningen från tidigare utbildningserfarenheter, där utbildningen som regel är mer styrd och strukturerad, och det kan vara svårt att finna en balans mellan strävan mot självständighet och behovet av stöd (Gardner, 2007).

Ali och Kohun (2006) diskuterar hur social isolering kan uppstå under olika faser av forskarutbildningen. Om kraven och förväntningarna på doktoranderna är vagt och otydligt formulerade kan en känsla av att vara utlämnad till sig själv uppstå redan i forskarstudiernas initiala skede. En andra fas relateras till uppstarten av forsknings- och avhandlingsarbetet. Detta ställer andra psykologiska och intellektuella krav än vad doktoranderna vant sig vid från tidigare studier 
och de som är oförberedda på förändringen kan känna sig osäkra och i stort behov av råd och stöd. Nästa fas relateras till den period då avhandlingsarbetet ska avgränsas och preciseras. Detta tydliggör det unika i varje avhandlingsprojekt och att doktoranden är mer eller mindre ensam om det. Slutligen diskuteras slutfasens alltmer intensifierade skrivarbete som ett moment som i mycket hög grad innebär ensamarbete, ibland helt i avsaknad av vardaglig social interaktion.

Andra orsaker till känslor av utanförskap och exkludering kan länkas till könsstrukturer och social klass. Peixoto (20I4) diskuterar flera studier som på olika sätt visar att kvinnor upplever sig vara mer utsatta och missgynnade i sin doktorandposition än män. Studierna kopplas till ett normsystem som är manligt kodat och på så vis främjar vissa beteenden framför andra. Samtidigt framhålls att detta bara handlar om en form av maskulinitet och att den exkluderar både kvinnor och män som inte kan iscensätta forskarrollen på det önskvärda sättet. Precis som med kön diskuterar Peixoto (a.a) social klass som en utestängningsmekanism som tenderar att göra akademin till en mera främmande plats för doktorander som är uppvuxna i miljöer utan akademiska utbildningstraditioner.

Nägra konsekvenser av doktoranders ensambet

Ensamhet och isolering kan generellt sett förstås som något som utmanar doktoranders trivsel och välmående och en socialt isolerad doktorandtillvaro kan leda till känslor av alienation och utanförskap (Jones, 2013). Mot denna bakgrund har doktoranders ensamhet uppmärksammats i studier som undersöker retention inom forskarutbildningen och i dessa beskrivs ensamhet som en viktig orsak till att doktorander lämnar forskarutbildningen utan att ta examen (Ali \& Kohun, 2006, 2007, 2009). En isolerad och ensam doktorandtillvaro kan också ha betydelse för den fortsatta akademiska karriären. Framförallt kan en ensam doktorandtid leda till en postdoktoral tillvaro med begränsade professionella kontakter, vilket innebär färre framtida arbetsmöjligheter och riskerar att leda mot fortsatt personlig isolering (jfr Peixoto, 20I4).

Andra studier diskuterar positiva effekter av social samvaro och social integration. Exempelvis framhåller Girves och Wemmerus (1988) att doktorander som utvecklar professionella relationer under sin doktorandtid tenderar att göra större framsteg under sin forskarutbildning. Vidare har Bauer och Green (1994) studerat effekten av att doktorander blir involverade i institutionens arbetsprocesser. Studien visar att doktorander som var tidigt involverade både var mer produktiva och fann sig bättre till rätta i doktorandtillvaron.

\section{Exempel på åtgärder för att motverka social isolering och ensambet}

Samtidigt som flera studier uppmärksammar doktoranders ensamhet och isolering har intresset för att skapa en mer samarbetsorienterad forskarutbildningskultur ökat (Stracke, 20I0). Det tilltagande intresset för forskarutbildningen som just utbildning och framväxten av mer strukturerade studiegångar kan förstås i detta perspektiv (Elmgren, Forsberg, Lindberg-Sand \& Sonesson, 2016). Det kanske tydligaste exemplet är när en grupp doktorander antas samtidigt och sedan följs åt som en kohort genom hela forskarutbildningen (t.ex. Ali \& Kohun, 2009). Ett annat exempel är olika former av forskarskolor, vilka blivit allt vanligare för att försöka skapa tydligare sammanhang inom forskarutbildningen. Detta gäller inte minst i Sverige (Degerblad \& Hägglund, 2002; Elmgren, Forsberg, Lindberg-Sand \& Sonesson, 2016).

Vidare kan handledningen organiseras såväl för att öka doktorandernas delaktighet i forskarutbildningsmiljön som för att stärka sammanhållningen i doktorandgruppen (t.ex. Fenge, 20I2; Stracke, 20Io). Därtill är handledaren den person som har mest insyn i doktorandens arbetsprocess. Detta, menar Janta, Lugosi och Brown (2012), innebär att handledaren bör ha både viljan 
och förmågan att tolka tecken på social isolering bland sina doktorander. I antologin Det goda seminariet framhålls dessutom seminariets viktiga roll för att främja inkludering, samarbete och jämställda relationer i forskarutbildningen (Cronqvist \& Maurits, 2016).

Andra aspekter som framhålls som betydelsefulla för att motverka isolering är att doktorander får en god introduktion till forskarstudierna, att sociala sammankomster organiseras när doktoranderna är nya i institutionsmiljön samt att det finns möjligheter till face-to-face kommunikation och stöd under den oftast ensamma perioden när avhandlingsarbetet ska färdigställas (Ali \& Kohun, 2007). Dessutom kan en rumslig aspekt beaktas. En avskild arbetsplats kan vara adekvat när avhandlingen ska skrivas samman, men kan vara en grund för social isolering i forskarutbildningens tidigare skeden (Janta, Lugosi \& Brown, 20I2).

\section{INTERVJUSTUDIEN: URVAL, GENOMFÖRANDE OCH ANALYS}

Intervjuerna med ensamarbetande doktorander vid Lunds universitet genomfördes under hösten 2013 och våren 2014 och hade karaktären av kvalitativa forskningsintervjuer (Kvale, 2009). För att komma i kontakt med intervjupersoner skickades ett brev via e-post till aktiva doktorander inom samtliga fakulteter. I brevet beskrevs studiens bakgrund och syfte och doktorander som arbetade ensamma och som var intresserade av att medverka uppmanades att anmäla sitt intresse. Som ensamarbetande doktorand definierades doktorander som inte bedrev sitt avhandlingsarbete inom ramen för en forskargrupp.

Eftersom det specifikt var ensamarbetande doktorander som efterfrågades kan urvalsstrategin beskrivas som ändamålsenlig. Detta betyder att undersökningsenheter - i detta fall intervjupersoner - inte väljs ut slumpmässigt, utan mot bakgrund av en förförståelse och att de avser att representera särskilda egenskaper eller kännetecken som förväntas möjliggöra en detaljerad förståelse för det problem som studeras (Berg \& Lune, 20I2; Ritchie, Lewis \& Elam, 2003; Silverman, 2005). En annan viktig urvalsaspekt inom kvalitativa undersökningar är att urvalet är heterogent inom den avgränsade grupp som är utvald för att studeras (Ritchie, Lewis \& Elam, 2003). Detta kan t.ex. handla om att en variation uppnås i fråga om kön, ålder, befattning och organisatorisk tillhörighet. Detta är som regel svårare att uppnå eftersom urvalet också är styrt av vilka som är tillgängliga och vilka som vill medverka i studien (Silverman, 2005). Sett till föreliggande undersökning skickades informationsbrevet till både män och kvinnor vid samtliga fakulteter och de tillfrågade var i skilda faser av forskarutbildningsprocessen. Samtidigt valde intervjupersonerna ut sig själva genom att aktivt ta kontakt och anmäla sitt intresse. Därmed har urvalet också ett tydligt inslag av självselektion, vilket givetvis kan ge en slagsida i fråga om vem som väljer att medverka (Trost, 20IO).

Av de 26 doktorander som intervjuades var betydligt fler kvinnor (19) än män (7). Merparten var omkring 30 år, en del var några år under 30 och några var äldre än 40 . Flest doktorerade inom Humanistiska och teologiska fakulteterna (IO). Knappt en handfull bedrev sina forskarstudier vid Naturvetenskapliga (4), Samhällsvetenskapliga (4) och Medicinska fakulteten (4). Ytterligare några doktorerade vid Lunds Tekniska Högskola (I), Konstnärliga (2) samt Juridiska fakulteten (I). Doktoranderna befann sig i skilda faser av forskarutbildningsprocessen. Merparten hade en doktorandtjänst vid intervjutillfället, medan några försörjde sig på annat sätt. En av intervjupersonerna var internationell doktorand.

Intervjuerna var semistrukturerade och utgick från en på förhand upprättad intervjuguide, i vilken ett antal övergripande teman och frågeområden var listade (t.ex. Seidman, 1998; Trost, 20IO). Intervjuerna varade mellan 45 och $I 20$ minuter och i samtliga fall spelades de in. 
Stora delar av det inspelade materialet transkriberades. Detta resulterade i en omfattande textmängd som reducerades och kondenserades i flera led. Utifrån intervjuguidens tema och andra intressanta aspekter som framträdde under intervjuerna identifierades först centrala problemområden. I ett textdokument sorterades därefter relevanta intervjucitat in under respektive problemområde och detta dokument utgjorde grunden för en fördjupad analys där mönster och motsättningar inom respektive område kunde utskiljas.

\section{ENSAMHET, SOCIALISATION OCH ERKÄNNANDE INOM FORSKARUTBILDNINGEN}

I det följande presenteras studiens empiriska material. Redovisningen är strukturerad utifrån olika problem som framträdde när de ensamarbetande doktoranderna reflekterade kring sin forskarutbildning och doktorandtillvaro. De problembilder som intervjupersonerna gav uttryck för analyseras utifrån studiens teoretiska perspektiv på ensamhet, socialisation och erkännande. I några avsnitt blir problembilderna även belysta utifrån ett genusperspektiv. Begrepp och perspektiv definieras parallellt med att intervjumaterialet redovisas och analyseras.

Intervjupersonernas erfarenheter presenteras både i löpande text och i form av citat. I anslutning till varje citat framgår om det är en kvinna eller man som citeras och vid vilken fakultet som intervjupersonen doktorerar vid.

\section{Den ämnesmässiga ensambeten}

Utifrån Westberg (20I2, s. 24) kan ensamhet definieras som "en subjektiv och smärtsam upplevelse av social brist" eller som "ett otillfredsställt behov av gemenskap". ${ }^{6}$ Känslan kan uppstå som en följd av åtminstone två olika situationer (Gierveld, 2006). Dels uppstår ensamhet i situationer där det existerande antalet relationer är färre än vad individen önskar, dels när den grad av närhet som eftersträvas inte realiseras. När studiens doktorander reflekterar kring ensamhet uppehåller de sig mindre kring antalet personer i det personliga nätverket och betydligt mer kring arbetsrelationernas kvalitativa dimension i form av innehåll och närhet. Ju mer doktorander arbetar, utvecklas och specialiseras inom sitt forskningsfält, i desto lägre grad verkar de uppleva att det finns någon initierad person att rådgöra med. Detta gör att doktorander på ett tidigt stadium - i några fall redan från början - kan uppleva en ämnesmässig ensamhet $i$ avhandlingsarbetet. Ensamhetskänslan kan även uppstå i relation till handledaren.

Vi pratar inte så jättemycket om vad vi gör ... vi har inte så mycket teoretiska diskussioner. [...] Och då kan man känna sig ensam, och extra mycket då om man faktiskt inte har så många att prata om sin forskning med. (Kvinna, Samhällsvetenskaplig fakultet)

I det här ämnet som jag forskar så tror jag nog att jag har gått om [handledaren] [...] och som jag stör mig på ganska mycket är att jag tycker att det är ganska uppenbart att hon inte förstår vad jag menar. Om jag lämnar in något till henne eller skickar något till henne för granskning och feedback, så får jag i princip aldrig någon vetenskaplig feedback. (Kvinna, Naturvetenskaplig fakultet)

Ämnesmässig ensamhet verkar i hög grad upplevas av ensamarbetande doktorander, i synnerhet i små forskningsmiljöer. Situationen kan bli särskilt problematisk i tvärvetenskapliga avhandlingsprojekt. En doktorand som arbetar tvärvetenskapligt beskriver hur den ene handledaren

6 Den andra definitionen har Westberg hämtat från Karlsson och Rider (2006, s. Io). 
har begränsade kunskaper i det ena ämnet, medan den andre inte upplevs kunna särskilt mycket om det andra. Detta innebär att det blir svårt att diskutera avhandlingsarbetet i sin helhet och att doktoranden känner sig utlämnad till sig själv. Situationen beskrivs som komplicerad och frustrerande.

\section{Självvald avskildhet, undvikandebeteende och att gömma sig}

Samtidigt som doktorander kan känna sig ensamma och att ensamhet ofta refererar till en problematisk situation kan frånvaron av sociala relationer också vara självvald och behöver inte alltid betraktas som ett problem. Westberg (20I2) skiljer i det här sammanhanget mellan ensamhet och avskildhet. Medan ensamhet refererar till en ofrivillig och besvärande brist på socialt samspel relaterar avskildhet till människors behov att dra sig undan för att kunna agera ostört. Behovet att avskilja sig från andra för att uppnå sina mål gäller i hög grad för forsknings- och avhandlingsarbete. Forskning förutsätter enskild reflektion och såväl institutions- som forskarutbildningsmiljöer är ofta starkt präglade av självständighetsideal.

Möjligheten till perioder av koncentrerat avskilt arbete framhålls också som en viktig förutsättning för avhandlingsarbetet. En av doktoranderna anser exempelvis att det är svårt att fokusera på skrivarbete i kontorslandskapet som han sitter i och arbetar därför mycket hemifrån. En annan doktorand beskriver universitetet som en fantastisk fristad för individer som är oerhört skickliga inom sitt ämne, men som har ett begränsat behov av sociala och professionella kontakter.

Samtidigt framhålls problematiska aspekter av möjligheten att dra sig undan, eftersom den i vissa fall kan medföra att doktorander väljer bort möjliga arbetsuppgifter eller kontakter som de känner sig osäkra eller otrygga inför, t.ex. institutionsmöten, seminarier, undervisning eller konferensmedverkan. En annan problematisk aspekt är att perioder av oro, ängslan och ångest kan hanteras genom att doktoranden isolerar sig. Därmed kan självvald avskildhet inte alltid tolkas som ett uttryck för ett kreativt och koncentrerat avhandlingsarbete. Ibland kan det snarare liknas vid ett undvikandebeteende eller ett sätt att gömma sig på.

\section{Vägen frän omedveten inkompetens till medveten kompetens}

Socialisation handlar om den process genom vilken individer lär sig och införlivar värderingar, färdigheter och normer som förutsätts för medlemskap i gruppen eller organisationen (t.ex. Charon, 2009). På så vis handlar doktoranders socialisation såväl om en gradvis avkodning av den akademiska miljön som om en väg mot social inklusion och gemenskap (jfr Jones, 2013).

Utifrån Beeler (199I) beskriver Ali och Kohun (2007) doktoranders socialisationsprocess som en rörelse från omedveten inkompetens till medveten kompetens. Att vara omedvetet inkompetent innebär att känna sig osäker utan att veta vilken kunskap eller information som saknas. Genom att bli medveten om krav och förväntningar i forskarutbildningsmiljön blir kunskapsbristerna medvetandegjorda och doktorander blir - i denna terminologi - medvetet inkompetenta. Trots detta kan doktoranden stanna kvar i en känsla av osäkerhet och vara omedveten om sin nyvunna och tilltagande kompetens. Den successivt ökade insikten leder emellertid till att doktoranden kan röra sig i den akademiska miljön med ett större mått av självsäkerhet. Detta är centralt för både forskarutbildningsprocessen och den postdoktorala karriären och benämns i termer av att vara medvetet kompetent.

De allra flesta doktorander som medverkar i studien känner tydligt igen sig i känslan av att vara omedvetet inkompetent. Detta innebär att deras första tid i forskarutbildningen i olika 
grad präglades av en känsla av ovisshet, utan att de riktigt kunde avkoda vilken kunskap eller information som de saknade.

Jag tycker att det har gått för mycket och onödigt lång tid för att försöka förstå vad det här är för någonting och vad det är jag vill göra. (Kvinna, Lunds Tekniska Högskola)

Jag vet inte vad som förväntas. [...] Jag har ingen som säger åt mig att det du gör, det är så en doktorand jobbar. Det är väl det jag kände med att inte ha en grupp, att vara ensam doktorand i största allmänhet, det är svårt med detta. (Man, Naturvetenskaplig fakultet)

Doktoranderna i studien delar erfarenheten av att ha tagit del av någon form av introduktionskurs under sin första tid på forskarutbildningen. Kursernas övergripande syfte är att introducera doktoranderna till forskarutbildningen och doktorandtillvaron och mot bakgrund av den förvirring som kan prägla den första studietiden bör betydelsen av introduktionskurser framhållas. Samtidigt visar materialet tydligt på att även doktorander som haft stor behållning av sin introduktionskurs kan uppleva en stark känsla av osäkerhet. Detta pekar på att introduktionskurserna i sig själva inte är tillräckliga för att komma till rätta med den osäkerhet som nyantagna doktorander kan uppleva. Detta vore ett orimligt krav att ställa på en introduktionskurs och att underskatta betydelsen av doktorandens arbetsvardag och forskarbildningsmiljön i sin helhet. Utan ett sammanhang kan vägen mot medveten kompetens - och att kunna navigera med säkerhet och självförtroende inom akademin - bli en solitär resa som inte alla klarar av. I rapporten Könsmedveten handledning diskuterar Schnaas (2OII) handledarens betydelse i sammanhanget, bland annat genom att peka på betydelsen av att handledaren hjälper till med att "synliggöra det osynliga", det som "sitter i väggarna". Dessutom ges flera konkreta tips på hur handledaren kan agera under inskolningen av nya doktorander.

\section{Den informella socialisationens kraft}

De primära socialisationsagenterna i doktorandernas socialisationsprocess, framhåller Gardner (20IO), är institutionens etablerade forskare och lärare. Genom sitt inflytande över både antagning och möjligheter till vidare anställning är de som etablerat sig inom akademin inte bara gatekeepers in i och ut genom forskarutbildningen. De överför också sina attityder, värderingar, förhållningssätt och prioriteringar i relation till forskning, undervisning och annat arbete. Detta sker både formellt och informellt. Formellt sker överföringen genom forskarutbildningsstrukturer som de är med om att etablera och upprätthålla och genom forskarutbildningskurser som de undervisar på. Den informella överföringen sker å andra sidan genom sociala möten och handlingsmönster som lokaliseras utanför de formella strukturerna och behöver inte alltid vara överensstämmande med officiella riktlinjer.

I takt med att forskarutbildningen $i$ allt högre grad har formaliserats som en utbildning med tydligare riktlinjer, mål och organisation blir de formella aspekterna av doktorandernas socialisation också allt viktigare. När doktoranderna problematiserar sina forskarstudier återkommer de emellertid till erfarenheter som hänvisar till de informella aspekterna av socialisationsprocessen. Framförallt pekar flera på förekomsten av ett individuellt förhållningssätt till arbetet som kan vara svårt att både förstå och tillämpa. Förhållningssättet kan framträda på skilda sätt, med varierad kraft och aktualisera olika slags problem eller utmaningar.

Ett exempel är att doktorander kan uppleva att de i hög grad förväntas utforma sina forskarstudier på egen hand medan utbildningsinslagen beskrivs som få och ibland obefintliga. Därmed kan forskarutbildningen upplevas som vag och konturlös medan handledningen och relationen 
till handledaren blir avgörande för möjligheten att få råd och stöd. Detta gör att doktoranden kan känna sig utlämnad till handledarens kunskaper och synsätt. Dessutom ökar risken för att handledningsbehovet blir större än vad handledarna har tid med eller vad tjänstetilldelningen medger och att handledarna möter förväntningar på att de ska kompensera för brister som doktoranderna upplever i forskarutbildningen som helhet.

En total känsla av att man ska bygga upp allting helt själv, och att veta vad det är som ska byggas upp på egen hand [...] Universitetet ger mig vissa ramar, ger mig en plats, ger mig pengar, ger mig böcker, en handledare, men därefter lämnas jag åt mitt eget öde. (Kvinna, Humanistiska och teologiska fakulteterna)

Ett annat exempel är att doktorander uppfattar att seniora forskare kan förmedla en bild av avhandlingsarbetet som en ensam och svår kamp. Om förhållningssättet får fäste i en forskarutbildningsmiljö kan problem och bekymmer som doktorander upplever normaliseras och bli betraktade som en naturlig del av forskarutbildningen. Då kan det också bli svårt att utskilja när doktorander bör agera självständigt och när de behöver stöd och vägledning. Dessutom kan förhållningssättet innebära att problemen individualiseras. Förklaringsmodellen för doktoranders olösta problem eller misslyckanden blir på så vis inriktad mot den enskilde doktorandens egenskaper och förmågor snarare än mot forskarutbildningen som en miljö och ett sammanhang.

Jag upplever att det är en miljö där det tas för givet att det här är en ensam kamp som man ska bemästra själv. Och gör man inte det så kanske man inte har där att göra. (Kvinna, Humanistiska och teologiska fakulteterna)

Och någonting som jag inte har sagt men som jag har tänkt mycket, är att de äldre eller de seniora forskarna på något sätt känner att man ska igenom den tuffa perioden i början [...] det är precis som att det är en del av forskarutbildningen, att man ska liksom ha det jädrigt kämpigt. Det är kanske därför jag känner också att de lyssnar liksom ... men det händer ingenting. För att de kanske känner att så här är det liksom och så kanske det var för dem också, vad vet jag? (Kvinna, Naturvetenskaplig fakultet)

Man förväntas att se det som ett kall. I det kanske också ligger att man inte ska klaga. Man ska kämpa sig igenom, inte vara illojal mot sin institution eller handledare. Och det kanske gör att många lider ganska mycket i sin tysthet tills det inte går längre. Och är man då väldigt ensam så kanske man inte fångas upp innan det är för sent. (Kvinna, Samhällsvetenskaplig fakultet)

Ytterligare ett exempel är att doktorander kan uppleva att det enskilda forskningsarbetet tillskrivs betydligt högre status än arbetsuppgifter som berör institutionens arbete i stort och ofta är mera kollektivt orienterade, t.ex. undervisning, pedagogiskt utvecklingsarbete, åtaganden i institutionsstyrelse eller engagemang i arbetsgrupper eller kommittéer. När detta är fallet, menar flera doktorander, finns det uppenbar risk för att det institutionsgemensamma arbetet vare sig synliggörs eller belönas i tillräcklig utsträckning. Detta lägger grunden för ett dilemma för doktorander som upplever det institutionsgemensamma arbetet som meningsskapande och utvecklande. Om de å ena sidan skruvar ned eller väljer bort sitt engagemang avstår de från arbete som de upplever som viktigt och utvecklande samtidigt som de bidrar till att reproducera strukturer som de är kritiska till. Om de å andra sidan bejakar engagemanget finns det risk för att arbetet vare sig synliggörs eller belönas i den utsträckning som de önskar. 
Det är ingen som tackar en för man tar hundratals timmar med undervisning och försöker engagera sig för studenter liksom, utan det är ju väldigt individualistiskt på institutionen. Det som räknas är det man producerar forskningsmässigt. (Kvinna, Naturvetenskaplig fakultet)

Jag blev engagerad i kollektiva processer och jag satt med i institutionsstyrelsen och i doktorandråd [...] Men man ska som sagt passa sig lite så att det inte blir för mycket. För ändå, någonstans, är det ingen som tackar dig för det. (Kvinna, Humanistiska och teologiska fakulteterna)

Problematiken reser flera viktiga frågor om doktorandernas institutionstjänstgöring. Enligt Högskoleförordningen (5 kap. $2 \S)$ är doktorandens huvudsakliga arbetsuppgift att ägna sig åt sin egen utbildning. Den som har doktorandanställning har emellertid också möjlighet att ägna sig åt andra arbetsuppgifter i form av forskning, utbildning och administration. Omfattningen är reglerad till maximalt $20 \%$ av full arbetstid och kan ge rätt till förlängning. Samtidigt som institutionstjänstgöringen kan vara både berikande och utvecklande - inte minst i relation till flera av examensmålen inom forskarutbildningen ${ }^{7}$ - är förlängningen av central betydelse för möjligheten att slutföra forskarstudierna inom utsatt tid. Hur den beräknas varierar dock mellan olika lärosäten. Därför är det viktigt för doktorander att informera sig om vilka regler och riktlinjer som gäller för förlängningen inom den givna forskarutbildningsmiljön (Sonesson $\&$ Lindberg Sand, 20I6).

\section{Svårnavigerade individualistiska forskarutbildningsmiljöer}

Olika doktorander träder in i forskarutbildningen med sin specifika bakgrund och erfarenhetsgrund och socialiseras därmed in i forskarmiljön utifrån skilda utgångspunkter (jfr Gardner, 2008). En av de mest uppmärksammade aspekterna handlar om hur kvinnor och män kan göra olika erfarenheter av akademin och forskarutbildningen. Sallee (20II) diskuterar exempelvis hur maskulinitets- och femininitetsnormer förhåller sig till varandra som motsatser och hur könsstereotypa institutionsmiljöer skapar olika förutsättningar för mäns och kvinnors socialisation i akademin. Medan maskulinitet kopplas samman med individuell styrka och konkurrens blir feminitet snarare sammankopplat med omsorg och eftersom män oftare identifierar sig med maskulinitetsnormer och kvinnor med femininitetsnormer blir förutsättningarna olika för män och kvinnor att agera i könsstereotypa miljöer. Enligt detta synsätt kan utpräglat individualistiska institutionsmiljöer förstås som präglade av maskulinitetsnormer, vilket innebär att kvinnor i högre grad riskerar att känna sig marginaliserade i dessa. Resonemanget ligger i linje med att flera av de kvinnor som intervjuats problematiserar sin tillvaro i miljöer som upplevs som utpräglat individualistiska.

Carter, Blumenstein och Cook (2013) beskriver vägen från nyantagen doktorand till självständig forskare som särskilt problematisk för kvinnor. En viktig aspekt är att kvinnor kan hamna i ett korstryck av förväntningar från den sociala och den akademiska sfären. I den förra kan kvinnor möta sociala och kulturella förväntningar på att vara passiva, sätta andras intressen framför sina egna och att underordna sig manlig auktoritet. Detta står i ett tydligt spänningsförhållande till den akademiska prestationen som å andra sidan handlar om att stå på sig, prioritera sin egen forskning och att hantera maktrelationer på ett självsäkert sätt. Mot denna bakgrund kan kvinnor komma att behöva hantera motstridiga förväntningar samtidigt som de inte kan räkna med någon förståelse för sin dubbla rolluppsättning från vare sig den akademiska eller den sociala sfären. Ingen av kvinnorna som medverkar i intervjustudien uppehåller sig explicit kring

7 Detta gäller kanske allra tydligast för möjligheten att undervisa i relation till examensmålet om att doktoranden ska utveckla sin färdighet och förmåga att stödja andras lärande. 
upplevelser av ett sådant korstryck. Däremot framhåller flera att kvinnor i mycket högre grad intresserar sig för och tar ansvar för det institutionsgemensamma medan män har närmare till hands att prioritera den egna forskningen.

Och det är också en jobbig skillnad mellan kvinnor och män, att det finns olika förväntningar utifrån. Jag tycker att det är skitjobbigt, jag har väldigt, väldigt svårt att säga nej till saker. Duktig-flicka-syndromet liksom. Det är därför jag inte kan fokusera på avhandlingsarbetet riktigt, för det kommer så många störmoment. Dels för att jag tycker att en del projekt är roliga, det här vill jag hoppa på liksom. Men mycket är att jag känner att jag måste ställa upp. Medan jag har en kollega då som är man, han svarar att nej, det har jag inte tid med. Och jag gör aldrig det. (Kvinna, Medicinsk fakultet)

Att kvinnor upplever att de i högre grad engagerar sig utanför sin egen forskning samtidigt som engagemanget inte alltid belönas eller premieras kan tolkas som att förväntningar på att vara osjälvisk och att inte prioritera sig själv följer med från den sociala till den akademiska sfären. I samma utsträckning som detta engagemang upplevs som osynliggjort och går ut över forsknings- och avhandlingsarbetet läggs en grund för en arbetssituation som enligt flera intervjupersoner leder till både stress och frustration.

Flera andra studier pekar på att akademin inrymmer arbetsuppgifter som har lägre status och att dessa länkar olika till mäns och kvinnors erfarenheter. Peixoto (20I4) diskuterar t.ex. hur arbetsuppgifter med lägre status - sådant som inte är forskning - tenderar att vara kvinnligt kodade och leda bort från fortsatta forskningsmöjligheter och prestigeuppdrag och Appel och Ingesson (2008) redovisar erfarenheter av att kvinnliga doktorander i högre grad både tillfrågas om och tar sig an administrativt arbete som vare sig kompenseras eller är meriterande.

\section{Tvivel, maskerad osäkerhet och bilden av den duglige doktoranden}

Flera intervjupersoner förmedlar att forsknings- och avhandlingsarbetet i perioder medför starka känslor av tvivel. Tvivlet kan handla om olika aspekter av forskningen och det kan ta sig flera olika uttryck. Doktorander kan vara osäkra på om de gör relevanta och riktiga vägval gällande t.ex. frågeformulering, avgränsning och metodval. Ibland kan de ställa sig frågan om vad deras forskning har för mening och i sin förlängning kan de tvivla på varför de överhuvudtaget genomför sitt avhandlingsarbete. En annan kritisk aspekt är att forskarutbildningen är tydligt avgränsad i tid samtidigt som forskningsarbetet är gränslöst i den meningen att det alltid går att utveckla, förbättra och förfina. Detta kan nära en känsla av att ha missat något väsentligt och att avhandlingsarbetet aldrig blir riktigt färdigt.

Trots tvivel och osäkerhet framhåller flera intervjupersoner att doktorander tenderar att försöka lösa sina problem på egen hand även i situationer där de hade behövt hjälp. Detta upplevs som ett korrekt sätt att agera i en miljö som uppfattas som starkt präglad av självständighet, effektivitet och kompetens.

Det känns som att jag behöver vara kompetent i min hantering av mina svårigheter. Och det har ingenting att göra med hur min handledare är mot mig. Utan mer som ett slags arbetsplatskultur, att människor är kompetenta liksom. De tar hand om sina problem. (Kvinna, Samhällsvetenskaplig fakultet)

Även om doktorander kan dölja eller maskera sina problem och tvivel finns en handledare som följer arbetsprocessen på nära håll och som därmed skulle kunna förutse eller identifiera problem som kan dyka upp längs vägen. Men enligt flera doktorander är handledarna inte alltid 
särskilt receptiva. En del handledare verkar snarare konservera bilden av den högpresterande och kompetenta student som antogs till forskarutbildningen.

Det kan betraktas som en stor skillnad mellan att vara talangfull och uppmärksammad och utvald student och att vara ny som doktorand. Och det tror jag inte att alla i handledarkollektivet och andra är så observanta på. Utan de ser fortfarande den talangfulle studenten. (Kvinna, Humanistiska och teologiska fakulteterna)

För min del så känner jag väl ändå samtidigt att alla de här seniora personerna som man har haft som lärare innan, de fortsätter ju ha den här bilden av en att man är väldigt duktig. Och väl därför inte heller ser det så allvarligt, utan tänker att den här personen klarar väl sig ur det i alla fall. (Kvinna, Naturvetenskaplig fakultet)

Kombinationen av att doktorander ogärna visar sin osäkerhet och att handledare kan konservera bilden av den högpresterande student som antogs till forskarutbildningen kan få problematiska konsekvenser. Medan doktorander som har bekymmer kan göra sitt bästa för att dölja sina problem kan handledare vara så fast i sin initiala bild att de inte förmår att tolka signaler på att något är fel. I så fall upprätthålls en bild av att saker och ting flyter på som de ska och problem som kanske måste lösas förträngs eller skjuts på framtiden.

\section{Det professionella erkännandets betydelse}

Doktoranders känslor av osäkerhet och tvivel aktualiserar betydelsen av erkännande inom ramen för forskarutbildningen. Ett erkännande kan förstås som en bekräftelse av en persons sakkunskap inom ett område och som ett uttryck för uppskattning av vad en person gjort eller presterat (Heidegren, 2009, s. I2). På så vis blir erkännandet av grundläggande betydelse för att en individ utvecklar en personlig identitet i form av en positiv självbild och det ger en viktig motbild till känslor av tvivel, osäkerhet och bristande självförtroende.

Mot denna bakgrund framstår inslag av erkännande och bekräftelse som en central aspekt av doktoranders professionella socialisation. Betydelsen aktualiserar frågor om hur forskarutbildningsmiljöns seminariekultur gestaltar sig, hur feedback på examinationer formuleras och hur det vardagliga mötet med kollegor på institutionen upplevs. Ett annat centralt område handlar om återkopplingen på forskning och avhandlingsarbete. I det sammanhanget framhåller doktorander den stora betydelsen av att inte bara få veta vad som kan göras annorlunda och bättre utan att också få bekräftelse för när ett arbetsmoment är väl utfört. Detta kan fungera stärkande och det kan ingjuta ibland välbehövligt mod i arbetsprocessen.

Samtidigt upplever några doktorander att de bedriver sin forskarutbildning med få och i perioder inga inslag alls av bekräftelse och erkännande. Detta gör doktorandtillvaron svårare. Även om det inte sker medvetet eller utifrån ett ont uppsåt kan ett uteblivet erkännande - eller en icke-respons - liknas vid en missaktning (Heidegren, 2009). Om färdigheter, progression och framsteg inte erkänns uteblir en bekräftelse av doktorandernas professionella identitet och de får istället försöka fylla ut hela självbilden på egen hand.

Även om intervjuerna inte explicit uppehåller sig kring erkännande i relation till kön kan det sociologiska begreppet sex role spill over vara intressant i sammanhanget (Gutek \& Cohen, 1992). Begreppet syftar på situationer där kvinnor betraktas och behandlas primärt som kvinnor och inte som kollegor eller representanter för sin profession och diskuteras av Husu (2005) som en form av dold diskriminering inom akademin. I samma utsträckning som en kvinnlig doktorand blir uppmärksammad för att vara kvinna snarare än för sina kompetenser och kvalifikationer går hon också miste om det erkännande som länkar till den professionella identiteten. 


\section{AVSLUTNING OCH UTVECKLINGSOMRÅDEN}

Intervjustudien visar på en rad olika problem som doktorander som arbetar ensamma kan möta under sin väg mot doktorsexamen och dessa bidrar till en fördjupad förståelse för varför ensamarbetande doktorander i flera avseenden verkar trivas sämre med sina forskarstudier än doktorander som ingår i en forskargrupp. En problembild länkar tydligt till situationen som ensamarbetande och handlar om känslan av ämnesmässig ensamhet och att vara utlämnad till sig själv i sitt avhandlingsarbete. Andra kritiska moment länkar till aspekter av forskarutbildningsmiljön och doktorandtillvaron som alla doktorander kan erfara, men som ensamarbetande doktorander menas vara särskilt känsliga eller sårbara inför. Detta handlar om bekymmer med att finna sig tillrätta i doktorandtillvaron och avkoda den akademiska miljön, om svårigheter att navigera i starkt individualistiskt orienterade arbetskulturer, att tvivla på sin förmåga och att sakna erkännande för sin kompetens och sina prestationer. Att ensamarbetande kvinnor framstår som en särskilt utsatt doktorandgrupp är en komplex fråga som självfallet är svår att besvara på ett absolut och entydigt sätt. I den här studien hänvisas framförallt till förekomsten av individualistiskt orienterade arbetsplatskulturer. I sådana miljöer, menar flera doktorander i studien, tenderar kvinnor att fara illa i högre grad än män. Individualistiska arbetsplatskulturer iscensätts i sin tur primärt genom institutionens seniora forskare och handledare som kanske inte alltid har sin roll i doktorandernas informella socialisation i åtanke. Samtidigt som forskarutbildningen genomgår en tilltagande formalisering kan det alltså vara viktigt att påminna om den informella socialisationens kraft och betydelse.

Vilka lärdomar kan då dras utifrån intervjustudien och vilka utvecklingsområden kan identifieras? Svaret på frågorna varierar med vilken forskarutbildningsmiljö som avses och vem som tillfrågas. Mot bakgrund av studiens resultat framträder emellertid ett antal olika utvecklingsområden och frågeställningar som kan vara intressanta att beakta för såväl forskarutbildningsansvariga på olika nivåer som för handledare och doktorander.

- Att ensamarbetande doktorander tidigt kan uppleva en ämnesmässig ensamhet i avhandlingsarbetet pekar på betydelsen av att finna samarbeten på institutionen, vid lärosätet eller i forskarvärlden i stort. Vilka möjligheter har doktorander som upplever en ämnesmässig ensamhet att etablera sådana samarbeten? På vilka andra sätt skulle en forskarutbildningsmiljö kunna motverka doktoranders känslor av ämnesmässig ensamhet?

- Forskning innebär en hel del självvald ensamhet i form av avskilt och koncentrerat forskningsarbete. Att dra sig undan från gruppen kan emellertid också handla om att undvika situationer eller uppgifter som upplevs jobbiga. När handlar doktorandens undandragning om att skaffa sig arbetsro och när blir en hög grad av isolerat arbete snarare att betrakta som ett uttryck för att doktoranden inte mår bra?

- För många doktorander är inledningen av forskarstudierna präglad av osäkerhet. Detta aktualiserar betydelsen av välplanerade introduktionskurser, men också av en forskarutbildningsmiljö som är inkluderande. ${ }^{8}$ Vilket studie- och arbetsklimat är det som de nyantagna doktoranderna kommer till i det här avseendet?

- Det kan vara svårt för doktorander att navigera i forskarutbildningsmiljöer som är utpräglat individualistiska. Finns det tendenser till en problematisk individualism i den aktuella

8 I rapporten Könsmedveten handledning ger Schnaas (20II, s. 59-63) flera konkreta tips och förslag på hur handledaren kan agera för att underlätta inskolningen av nya doktorander. 
forskarutbildningsmiljön? Hur tar denna sig uttryck och vad betyder förhållningssättet för doktoranderna och för utvecklingen av forskarutbildningsmiljön i stort?

- Det verkar finnas en diskrepans mellan formaliserade aspekter av forskarutbildningen och doktoranders informella socialisation. Hur relaterar informella attityder och stämningar i forskarutbildningsmiljön till mål, föreskrifter och direktiv på olika nivåer? Rör sig informella stämningar och formella aspekter i samma riktning eller drar de iväg åt olika håll?

- Seniora forskares förhållningssätt till sitt arbete har stor betydelse för hur doktoranderna socialiseras in i det akademiska arbetet. Hur ser de seniora forskarna på sin roll som centrala aktörer i doktorandernas socialisationsprocess? Vilka olika förhållningssätt till det akademiska arbetet kan utskiljas i handledargruppen och hur kan dessa förstås utifrån ett socialisationsperspektiv?

- Samtidigt som doktorander kan känna starka tvivel är det ingen självklarhet att fråga om hjälp. Vilket klimat kan utskiljas i det här avseendet? Kommunicerar doktoranderna sina frågor? Hur receptiva är handledare till signaler som tyder på att doktoranden gått vilse och är i behov av vägledning?

- Erkännandet av doktoranders kunskaper och kompetens motverkar känslor av osäkerhet och tvivel och är en central aspekt av deras utveckling mot en professionell identitet. ${ }^{9}$ Vilken plats har erkännande och bekräftelse i den givna forskarutbildningsmiljön? Med vilken frekvens och på vilka sätt får doktoranderna återkoppling på sitt arbete?

- Flera studier påvisar att kvinnor på olika sätt mår sämre än män under sina forskarstudier. Hur kan ovanstående frågor diskuteras och förstås utifrån en genusdimension?

\section{FÖRFATTARPRESENTATION}

Ola Holmström är filosofie doktor i sociologi och han är verksam vid avdelningen Kvalitet och utvärdering och institutionen för Utbildningsvetenskap vid Lunds universitet. Han har flera års erfarenhet av utvärdering och forskning inom det högskolepedagogiska området. Häribland har han varit projektledare inom ramen för de senaste årens utvärderingar av Lunds universitets forskarutbildning.

\section{REFERENSER}

Ali, A. \& Kohun, F. (2006). Dealing with Isolation Feelings in IS Doctoral Programs, International Journal of Doctoral Studies, I, 2I-33.

Ali, A. \& Kohun, F. (2007). Dealing with Social Isolation to Minimize Doctoral Attrition - A Four Stage Framework, International Journal of Doctoral Studies, 2, 33-49.

Ali, A. \& Kohun, F. (2009). Cultural Influence on Social Isolation in Doctoral Programs and Doctoral Attrition - A Case Study, Information Systems Education Journal, 7(64), I-7.

Appel, M. \& Ingesson, O. (2008). Arbetsförhällanden för kvinnor som är doktorander. En intervjustudie. Enheten för kvalitet och utvärdering. Uppsala universitet.

Bauer, T. N. \& Green, S. B. (1994). Effect of Newcomer Involvement in Work Related Activities: A Longitudinal Study of Socialization, Journal of Applied Psychology, 79, 2II-223.

Berg, B. L. \& Lune, H. (20I2). Qualitative Research Methods for the Social Sciences. Upper Saddle River, NJ: Pearson.

Beeler, K. D. (199I). Graduate Student to Academic Life: A Four-stage Framework, NASPS Journal, 28, I63-7I. Carter, S., Blumenstein, M. \& Cook, C. (2013). Different for Women? The Challenges of Doctoral Studies in Teaching, Teaching in Higher Education, I8, 339-351.

9 Schnaas (20II, s. 78-80) ger också flera förslag på hur återkoppling till doktorander kan utformas, såväl i en generell mening som utifrån kön. 
Charon, J. M. (2009). Symbolic Interactionism. An Introduction, An Interpretation, An Integration. Englewood Cliffs, NJ: Prentice-Hall.

Cronqvist, M. \& Maurits, A. (red) (2016). Det goda seminariet. Forskarseminariet som lärandemiljö och kollegialt rum. Göteborg, Stockholm: Makadam förlag.

Degerblad, J.-E. \& Hägglund, S. (2002). Tradition och förnyelse i svensk forskarutbildning. Högskoleverkets rapportserie 2002:26. Stockholm: Högskoleverket.

Doktorandspegeln. En enkätom doktorandernasstudiesituation. Rapport 20I6:18. Universitetskanslersämbetet.

Elmgren, M., Forsberg, E., Lindberg-Sand, Å. \& Sonesson, A. (2016). The Formation of Doctoral Education. Lunds universitet: Media-Tryck.

Fenge, L.-A. (20I2). Enhancing the Doctoral Journey: The Role of Group Supervision in Supporting Collaborative Learning and Creativity, Studies in Higher Education, 37, 40I-4I4.

Gardner, S. K. (2007). I Heard it Through the Gravepine: Doctoral Student Socialization in Chemistry and History, Higher Education, 54, 723-740.

Gardner, S. K. (2008). Fitting the Mold of Graduate School: A Qualitative Study of Socialization in Doctoral Education, Innovative Higher Education, 33, I25-138.

Gardner, S. K. (20IO). Faculty Perspectives of Doctoral Student Socialization in Five Disciplines, International Journal of Doctoral Education, 5, 39-53.

Gierveld, J., van Tilburg, T. \& Dykstra, P. A. (2006). Loneliness and Social Isolation. I Vangeslisti, A. \& Perlman D. (red.), Cambridge Handbook of Personal Relationships (485-500). Cambridge: Cambridge University Press.

Girves, J. E. \& Wemmerus, V. (1988). Developing Models of Graduate Student Degree Progress, Journal of Higher Education, 59, 163-189.

Gutek, B. A. \& Cohen, A. G. (1992) Sex ratios, sex role spill over, and sex at work: a comparison of men's and women's experiences, s 33-50 i Albert J. Mills och Peta Tancred (red.) Gendering Organizational Analysis. Newbury Park: Sage.

Heidegren, C.-G. (2009). Erkännande. Stockholm: Liber.

Holmström, O. (2013). Forskarutbildningen vid Lunds universitet. Perspektiv frän doktorander, doktorsalumner och handledare. Rapport nr. 2013:270. Lunds universitet: Media-Tryck.

Holmström, O. (2OI4). Internationella doktorander om forskarutbildningen vid Lunds universitet. Rapport nr. 20I4:274. Lunds universitet: Media-Tryck.

Holmström, O. (2016). Ensamhet, socialisation och erkännande. Ensamarbetande doktorander om sin arbetssituation och doktorandtillvaro. Rapport nr. 2016:277. Lunds universitet: Media-Tryck.

Husu, L. (2005). Dold könsdiskriminering på akademiska arenor - osynligt, synligt, subtilt. Högskoleverket. Rapport 2005:4I.

Högskoleförordningen (1993:100).

Janson, A., Howard, L. \& Schoenberger-Orgad, M. (2004). The Odyssey of Ph.d. Students Becoming a Community of Practice, Business Communication Quarterly, 67, I68-18I.

Janta, H., Lugosi, P. \& Brown, L. (2012). Coping With Loneliness: A Netnographic Study of Doctoral Students, Journal of Further and Higher Education, 38, 553-57I.

Jones, M. (2013). Issues in Doctoral Studies: Forty Years of Journal Discussion: Where Have We Been and Where are We Going?, International Journal of Doctoral Studies, 8, 83-IO4.

Karlsson, M. \& Rider, S. (20I0). Inledning. I Karlsson, M. \& Rider, S. (red.), Den moderna ensamheten (7-I2). Stockholm/Stehag: Symposion.

Kvale, S. (2009). Den kvalitativa forskningsintervjun. Lund: Studentlitteratur.

Peixoto, A. (2014). De mest lämpade - en studie av doktoranders habituering på det vetenskapliga fältet. Gothenburg Studies in Work Science nr I4.

Ritchie, J., Lewis, J. \& Elam, G. (2003). Designing and Selecting Samples. I Ritchie, J. \& Lewis, J (red.), Qualitative Research Practice. A Guide for Social Science Students and Researchers. Thousand Oaks, CA: SAGE. 
Sallee, M. W. (20II). Performing Masculinity: Considering Gender in Doctoral Student Socialization, The Journal of Higher Education, 82, 187-216.

Schnaas, U. (2OII). Könsmedveten forskarhandledning - teoretiska utgångspunkter och praktiska erfarenheter. Uppsala universitet. Rapportserien från Avdelningen för universitetspedagogisk utveckling. Rapport nr II.

Seidman, I. (1998). Interviewing as Qualitative Research. A Guide for Researchers in Education and the Social Sciences. New York: Teachers College Press.

Silverman, D. (2005). Doing Qualitative Research. Thousand Oaks, CA: SAGE.

Sonesson, A. \& Lindberg-Sand, Å. (20I6). Forskarhandledningens ramförutsättningar. I Brodin, E., Lindén, J., Sonesson, A. \& Lindberg-Sand, Å. (red.): Forskarhandledning i teori och praktik. Lund: Studentlitteratur.

Stracke, E. (20I0). Undertaking the Journey together: Peer Learning for a Successful and Enjoyable PhD Experience, Journal of University Teaching \& Learning Practice, 7(I), I-IO.

Trost, J. (2010). Kvalitativa intervjuer. Lund: Studentlitteratur.

Westberg, N. (2012). Meddelanden frän enskildheten. En sociologisk studie av ensamhet och avskildhet. Göteborg: Daidalos. 